九州大学学術情報リポジトリ

Kyushu University Institutional Repository

\title{
Influence of Moisture Content on the Mechanical Properties of Soybeans at Cryogenic Temperatures
}

Shemsanga, Kassim H. H. Laboratory of Agricultural Process Engineering, Faculty of Agriculture, Kyushu University Uchida, Susumu

Laboratory of Agricultural Process Engineering, Faculty of Agriculture, Kyushu University

Ishibashi, Sadato

Laboratory of Agricultural Process Engineering, Faculty of Agriculture, Kyushu University

https://doi.org/10.5109/23783

出版情報：九州大学大学院農学研究院紀要. 28 (2/3)，pp. 123-134，1983-12. Kyushu University バージョン：

権利関係 : 


\title{
Influence of Moisture Content on the Mechanical Properties of Soybeans at Cryogenic Temperatures
}

\author{
Kassim H. H. Shemsanga, Susumu Uchida \\ and Sadato Ishibashi \\ Laboratory of Agricultural Process Engineering, Faculty of \\ Agriculture, Kyushu University 46-05, Fukuoka 812 \\ (Received 0 ctober 6, 1983)
}

\begin{abstract}
Mechanical properties of soybeans at cryogenic temperatures between $-20^{\circ} \mathrm{C}$ and $-120^{\circ} \mathrm{C}$ were investigated at various moisture contents. The materials were spray frozen using liquefied nitrogen to an accuracy of $12^{\circ} \mathrm{C}$. The frozen materials were then compressed at the temperature to which they were frozen on a $0.7 \mathrm{~mm}$ cylindrical plunger by a Universal Testing Machine. From the force-deformation curves obtained, stress to rupture point, stiffness and rupture energy were determined. These parameters were found to be significantly affected by the freezing temperature and moisture content. Between $9.8 \%$ and $23.6 \%$ moisture contents, the parameters were decreased as the moisture content was increased. However, the stress to rupture point and rupture energy were increased at $20.9 \%$ moisture content between $-60^{\circ} \mathrm{C}$ and $-120^{\circ} \mathrm{C}$. Between $23.6 \%$ and $31.3 \%$ moisture contents the parameters were increased as the moisture content was increased. As the moisture was increased above $31.3 \%$ to $49.4 \%$, the parameters were decreased. The parameters were increased again when the moisture content was increased again to $56.2 \%$. At $23.6 \%$ moisture content, the parameters were observed to attain the lowest value followed by those values obtained between 44.7 \% and 49.4 $\%$ moisture contents The highest values were either obtained at $31.3 \%$ or 56.2 $\%$ depending on the freezing temperature.
\end{abstract}

\section{INTRODUCTION}

Plant and animal materials consists of many cells containing and surrounded by a liquid. The liquid depending on the material contains various types of substances in solution or suspension. When the materials are cooled below $0^{\circ} \mathrm{C}$, ice crystals are formed. Most of the crystals have been reported to be formed between $-1.8^{\circ} \mathrm{C}$ and $-4^{\circ} \mathrm{C}$. But small amounts may still continue to freeze out until $-57^{\circ} \mathrm{C}$ is reached. The amount of the crystals formed at any given temperature seldom varies with the different freezing rates, but the size of the crystals varies inversely with the speed of freezing. The size of the crystals on the other hand affect the mechanical properties of the frozen materials. Therefore, the freezing rate will determine the mechanical properties of the frozen materials.

Cryogenic temperatures have become essential in some processing operations from both quantity and quality stand point of view. For example, cer- 
tain synthetic rubber cannot be produced without access to temperatures in the range of $-70^{\circ} \mathrm{C}$. Chilling of aluminium has been found to be useful in controlling age-hardening process. In the processing industry, low temperatures are used in the separation of crystals from solutions. Cotton seed oil is stored between $-10^{\circ} \mathrm{C}$ and $4^{\circ} \mathrm{C}$ to allow the stearin to collect and settle out. Fats from alcoholic solutions of perfume concentrates are separated by freezing so as to prevent special odors distruction by high temperature methods.

In metals, many transition phenomena have been reported to occur at low temperatures. It should therefore be expected that similar transitions should occur in biological materials. However, as biological materials contain water, the properties of these materials at low temperatures could, be more complicated than those of metals. For example it has been reported by Jordan et al (1982) that lettuce seeds are not injured when frozen to $-196^{\circ} \mathrm{C}$ if their moisture content is between $5 \%$ and $13 \%$. However, the seeds were reported to be injured when their moisture content was increased from $13 \%$ to $16 \%$. Therefore, the effect of freezing on the seeds depends directly on the moisture content. This should also apply to all biological materials.

Many reseachers have been involved in studying the effect of freezing on biological materials. Most of the researchers however, have been involved in studying the effect of freezing rates on the quality of the frozen materials. One of the quality parameters which researchers have gained interest is texture of the frozen materials. However, most of the texture studies have been conducted after the frozen materials have been thawed, such as in drip tests. The results from these tests have been taken as a measure of the mechanical properties of the frozen material in many cases. Such a method should be considered to be indirect as the results obtained indicate both freezing and thawing effects. But according to Fennema (1975) thawing should be regarded as the greater potential source of damage than freezing. It should, therefore be understood that, the texture results so far reported through the indirect methods, do not represent the true mechanical properties of the frozen materials. Given mechanical properties of the frozen materials will only be correct if the materials are tested at the temperature at which they have finally been frozen to.

It is therefore necessary that, investigations on the low temperature properties of biological materials should take into consideration of the moisture content of the materials, in addition to the final freezing temperature and the freezing rate. With this understanding in mind, the study was conducted so as to obtain more precise data on the effect of moisture content on the mechanical properties of soybeans at cryogenic temperatures.

\section{LITERATURE REVIEW}

Effect of freezing on biological materials has been reported by Brown (1967) and Hoeft et al (1973). The researchers reported that freezing could cause shattering of the frozen materials depending on the freezing rates. Brown (1977) reported that excessive freezing rates cause cracking or shat- 
tering of biological materials. Firmness of apple tissue at low temperatures was observed to increase with decrease in freezing temperature by Sterling (1968). Texture of frozen tomato slices has been reported to be improved by rapid liquid nitrogen freezing by Hoeft et al (1973). Brown (1967) reported that strawberries which were spray frozen by liquid nitrogen had low quality decline when stored at $-24^{\circ} \mathrm{C}$ compared to those which were blast frozen.

Desrosier (1970) observed that even at $-34^{\circ} \mathrm{C}$ there remains some noncrystal mater in fish. This has been reported to be due to the composition of the living cells which include both organic and inorganic substances, such as salts and sugars and acids in aqueous solutions and more complex organic molecules such as proteins which are colloidal suspensions. Love (1966) also reported that a fraction of water (3.7-17 \%) in muscle of cod fish remains bound to the protein at $-34^{\circ} \mathrm{C}$. The percentage of the unfrozen mater will depend on the freezing rates. Love (1966) observed that in prerigor muscles of fish frozen rapidly contained $39.8 \%$ of ice while the more slowly frozen contained 54\%. Apart from this the amount of the ice formed will depend on the availability of free fluid in the material. According to Desrosier (1970) bound water exists in proportion to the free water content rather than to the solids material of the system. The author further expressed that, free water exhibits the physical and chemical properties of liquid water and freezed according to its condition of solution. Love and Haraldsson (1961) reported that in pre-rigor muscles of fish a greater proportion of water is combined with the protoplasmic jelly, thus slowing down the rate of movement of free water and hence ice crystal growth.

Liquid nitrogen immersion of SetariaUterescense seed has been found to be increased in their germination by liquid nitrogen immersion (Joardan et al, 1982). It is interesting to note that, seeds were observed not to have been changed marphologically or cracked. The only visible change through electronic microscope was in the embryo secretory epithilium.

\section{EXPERIMENTAL MATEKIALS AND METHODOLOGY}

Soybean of the variety Akisengoku was bought from Farmers Cooperative Union in Fukuoka city in September, 1982. The materials were stored in a refrigerator until the tests were conducted. The moisture content of the materials was varied by adding different volumes of water to equal amounts of the samples put into plastic bags. The samples were then sealed and turned several times until all the added water had been absorbed. The soaked materials were then kept at $10^{\circ} \mathrm{C}$ for 48 hours to allow the absorbed water to penetrate to the center of the grains.

\section{LIQUID NITROGEN SPRAY FREEZER}

The spray freezer was constructed from plastic pipes of internal diameter of $76 \mathrm{~mm}$. The whole set up of the apparatus is shown in Fig. 1. The liquid nitrogen was forced into the freezer through a valve at a pressure of 


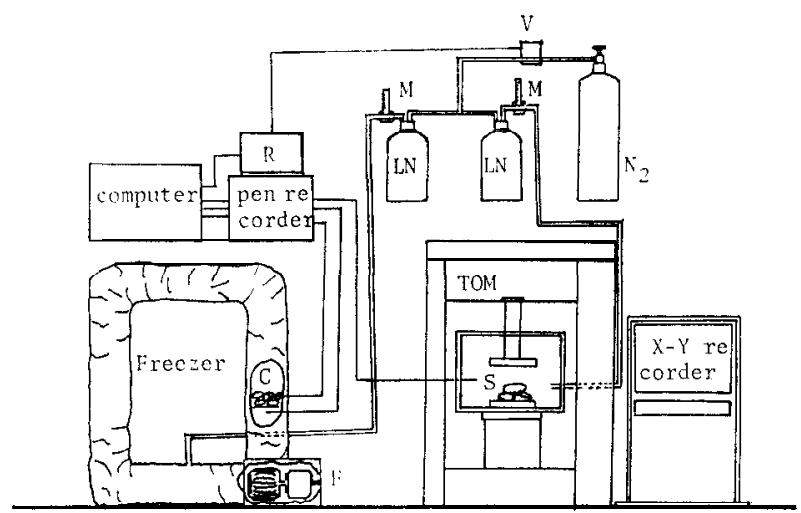

Fig. 1. Schematic diagram of experimental apparatus showing the spray freezer and compression testing machine. C, freezing chamber; $F$, fan and motor; S, compression chamber; V, magnetic valve; $M$, flow meter; $\mathrm{R}$, relay circuit; $\mathrm{LN}$, liquid nitrogen gas; $\mathrm{N}_{\mathbf{2}}$, dry nitrogen gas; TOM, Universa! Testing Machine.

one atmosphere obtained from dry nitrogen gas held in a tank at 145 atmospheres. The liquid nitrogen was partially liquefied on passing through the valve. The freezing gas was circulated through the freezer by a fan placed below the freezing chamber. The fan was driven by a 12 volt DC motor.

The temperature of the freezing gas was controlled by a heater placed immediately before the fan, not shown in the figure. The temperature was monitored by a copper-constatan thermocouple. Apart from recording the temperature of the freezing gas and sample on a pen recorder, the temperatures were recorded on a micro-computer (COMMODORE, PET 2001). This was achieved by connecting the thermocouple to a recorder (TAKEDA, TR 2721) and feeding it into the computer. The temperature of the freezing gas was controlled automatically by the computer through a relay which controlled the operation of the heater and the valve controlling the charging of the nitrogen gas. The controlleable range of the temperature was from $-20^{\circ} \mathrm{C}$ to $-120^{\circ} \mathrm{C}$ to an accuracy of $\pm 2.0^{\circ} \mathrm{C}$. At any given freezing temperature, 10 specimens were frozen together. One of the specimens was supplied with a thermocouple to its center. When the temperature at the center of the specimen was equal to the temperature of the freezing gas, one of the specimens was taken out of the freezing chamber, using a pin set and placed into a plastic holder which has been cooled to the same temperature as the sample has been cooled or frozen to. This was to avoid temperature rise of the specimens when being transfered to the compression chamber.

\section{COMPRESSION TEST}

The frozen specimens were compressed by a $490 \mathrm{~N}$ load cell attached to a Universal Testing Machine (SHINKOH, TOM 10000X). The specimen was 
placed on a cylindrical plunger surrounded by a spongy whose hardness was assumed to be negligible. The spongy acted as a supporting device of the specimen which otherwise would be unstable on the plunger. The plunger was $0.7 \mathrm{~mm}$ in diameter and $4 \mathrm{~mm}$ high. The plunger was made from hardened stainless steel drill bit which was fixed on a steel plate. The plunger and the load cell were placed into an insulated chamber which was also cooled to the same temperature as that of the specimens. The specimens were compressed at $5 \mathrm{~mm} / \mathrm{min}$ and the force-deformation curve was traced on an X-Y pen recorder. For each freezing temperature and mosture content, 5 specimens were tested.

\section{RESULTS AND DISCUSSION}

The characteristics of the force-deformation curves were observed to be dependent on the freezing temperature and the moisture content of the materials as shown in Fig. 2. At low moisture contents, the curves were more visco-elastic than at high moisture contents at room temperature. At cryogenic temperatures, the curves tended to be more linear immediately after contact with the plunger. At these temperatures and high moisture content, the linearlity was more defined below $-40^{\circ} \mathrm{C}$. At -100 and $-120^{\circ} \mathrm{C}$ at $9.8 \%$ moisture content, the force-deformation curves became erratic below the rupture point. That is, it seemed that minor flows were being created or being propagated as the specimens were being compressed. In most of the specimens at $-60^{\circ} \mathrm{C}$ the bio-yield and the rupture points were observed at the same point, indicating that the specimen reached plastic equilibrium.

From the force-deformation curves, stress to rupture, rupture energy and stiffness were determined. The results for these parameters were statistically analized using factorial design, (Woolf, 1968) as shown in Table 1. The analysis of variance shows that the moisture content as well as the freezing temperature affected the investigated parameters significantly at $1 \%$ level of probability. Moreover, interaction between moisture content and freezing tempererature was observed to be significant at $1 \%$ level of probability. Due to this interaction, it is difficult to describe precisely the effect of temperature 01

Table 1. Analysis of variance for mechanical properties of soybeans at cryogenic temperature. M: Moisture content D. F. -Degrees of freedom M. S. = Means square

\begin{tabular}{|c|c|c|c|c|c|c|}
\hline \multirow{3}{*}{ Source of } & \multirow{2}{*}{\multicolumn{2}{|c|}{ Rutere force }} & \multirow{2}{*}{\multicolumn{2}{|c|}{ Stiffness }} & \multirow{2}{*}{\multicolumn{2}{|c|}{ Rupture energy }} \\
\hline & & & & & & \\
\hline & D. F. & M.S & D.F. & M.S. & D.F & $M . S$ \\
\hline Total & 319 & & 314 & & 318 & \\
\hline Moisture & 10 & $174.05^{* * *}$ & 10 & $1387.99 * *$ & 10 & $12.99 * *$ \\
\hline Temp & 5 & $524.19 * *$ & 5 & $3020.28 * *$ & 5 & $37.38^{* *}$ \\
\hline Temp $\times M$ & 35 & $39.52 * *$ & 35 & $176.96 * *$ & 35 & $3.61^{* *}$ \\
\hline Error & 279 & 2.89 & 274 & 21.77 & 268 & 0.60 \\
\hline
\end{tabular}

** Significant at $1 \%$ level of probability 


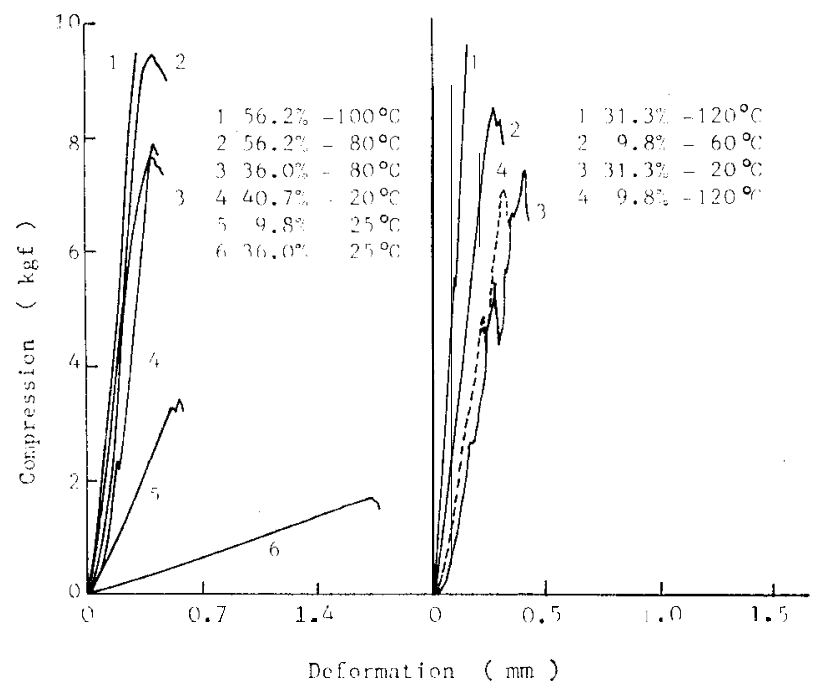

Fig. 2. Force-deformation curves for soybeans at different moisture contents and freezing temperatures.

moisture content on these parameters. These parameters have therefore, been described in general terms.

Fig. 3 shows the variation of stress to rupture with moisture content at the various freezing temperatures. At room temperature as the moisture content was increased, the stress decreased curvilinearly as expected. This phenomenon was also observed at $-20^{\circ} \mathrm{C}$ and $-40^{\circ} \mathrm{C}$, but only up to $31.3 \%$ and $23.6 \%$ moisture contents, respectively. Above these moisture contents, the stress at $-20^{\circ} \mathrm{C}$ and $-40^{\circ} \mathrm{C}$ was increased, attaining a peak at $36.0 \%$. Below $-40^{\circ} \mathrm{C}$ the stress was decreased to a minimum as the moisture content was increased from $9.8 \%$ to $23.6 \%$ after being increased at $20.9 \%$. As the moisture content was increased further from $23.6 \%$ to $31.3 \%$, the stress also increased, obtaining a peak at the later moisture content. The stress decreased again when the moisture content was increased from $31.3 \%$ to $49.4 \%$, above which it increased again up to $56.2 \%$. The stress was found to be highest at the $56.2 \%$ moisture content at $-40^{\circ} \mathrm{C}$ and $-120^{\circ} \mathrm{C}$. At the other temperatures, the stress was highest at $31.3 \%$ below $-40^{\circ} \mathrm{C}$ and $36 \%$ at $-20^{\circ} \mathrm{C}$.

Between $9.8 \%$ and $20.9 \%$ moisture contents, as the temperature was decreased, the stress was increased to an optimum value at $-80^{\circ} \mathrm{C}$. Below this temperature, the stress was decreased up to $-120^{\circ} \mathrm{C}$ in order of the decreasing temperature. At the other moisture contents, the stress was decreased as the freezing temperature was decreased up to $-120^{\circ} \mathrm{C}$. The only deviation was observed at $31.3 \%$ and $40.7 \%$ moisture contents where the stress was found to be optimum at $-100^{\circ} \mathrm{C}$.

Stiffness of the materials is shown in Fig. 4. The stiffness was taken as the gradient of the linear portion of the force-deformation curve. This linear portion was easily identified at low mosture contents and at low freezing tem- 


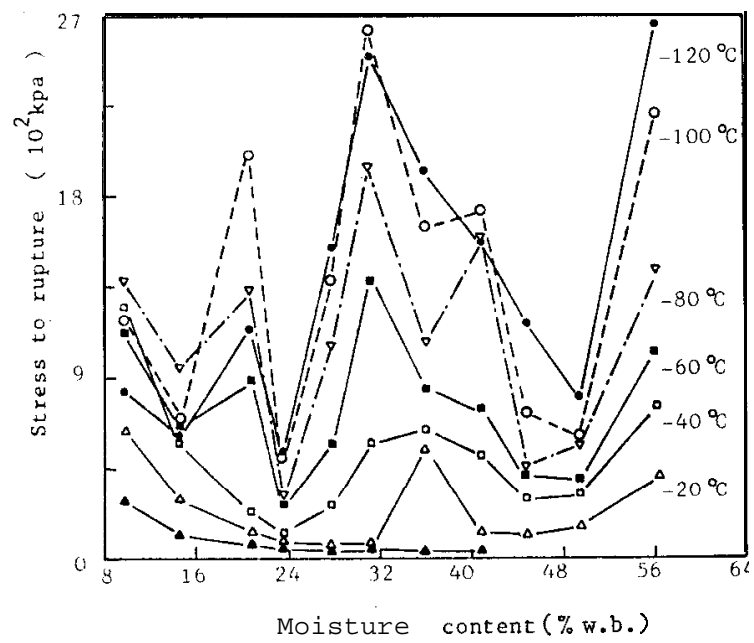

Fig. 3. Effect of moisture content on stress to rupture of soybeans at cryogenic temperatures.

peratures. At high moisture contents and above $-40^{\circ} \mathrm{C}$, this portion was taken at 0.53 of the total length of the force-deformation curves. This was the point where most of the curves showed some linearlity.

As in the stress to rupture point, the stiffness was observed to have a minimum value at $23.6 \%$ moisture content at $-40^{\circ} \mathrm{C}$ and below. The second lowest stiffness values were obtained at $44.7 \%$ at $-100^{\circ} \mathrm{C}$ and above. A peak in the stiffness was observed at $36 \%$ moisture content between $-20^{\circ} \mathrm{C}$ and $-80^{\circ} \mathrm{C}$. At $-100^{\circ} \mathrm{C}$ and $-120^{\circ} \mathrm{C}$, the peak was observed at $31.3 \%$ moisture content. The stiffness was found to be highest at $56.2 \%$ moisture content at

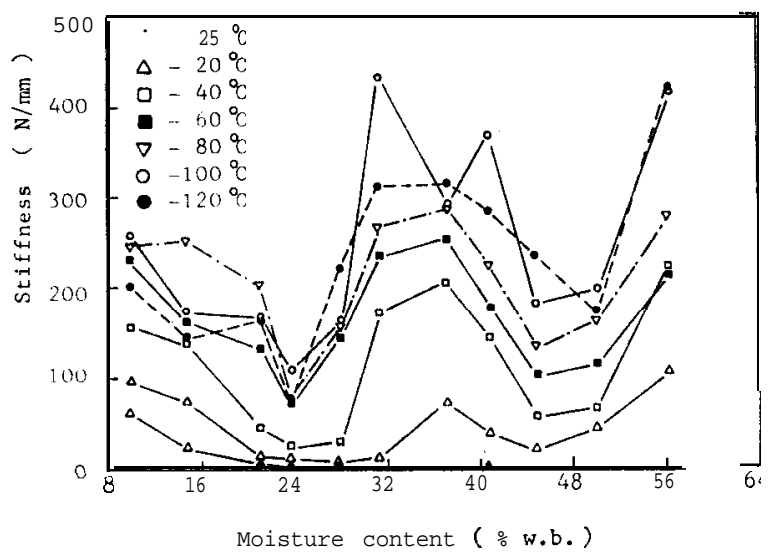

Fig. 4. Variation of stiffness with moisture content in soybeans at cryogenic temperatures. 
-20, -40 and $-120^{\circ} \mathrm{C}$. At the other temperatures, the highest stiffness values were at the peaks mantioned above.

Generally as the temperature was decreased from room temperature to $-100^{\circ} \mathrm{C}$, the stiffness was increased in order of decreasing temperature. Between $9.8 \%$ and $20.9 \%$ moisture contents, the stiffness was increased as the temperature was decreased up to $-80^{\circ} \mathrm{C}$. Below this temperature the stiffness was decreased up to $-120^{\circ} \mathrm{C}$. The stiffness was found to be highest at $-100^{\circ} \mathrm{C}$ at $9.8 \%, 23.6 \%, 31.3 \%, 40.7 \%$ and $49.4 \%$ moisture contents.

The rupture energy is shown in Fig. 5. The energy was taken as the area of the force-deformation curve between the origin and the rupture point. This area was measured using a planimeter. As in the stress and stiffness, the lowest energy was observed at $23.6 \%$ moisture content except at $-120^{\circ} \mathrm{C}$ where it was observed at $9.8 \%$. At $-20^{\circ} \mathrm{C},-40^{\circ} \mathrm{C}$ and $-120^{\circ} \mathrm{C}$ the energy peaked at $36.0 \%$ moisture content. At the other temperatures the peak was observed at $31.3 \%$ moisture content. Between $9.8 \%$ and $23.6 \%$ and at 49.4 $\%$ moisture contents, the highest rupture energy was obtained at $-100^{\circ} \mathrm{C}$. At the other moisture contents; except at $27.9 \%$, the highest rupture energy was observed at $-120^{\circ} \mathrm{C}$.

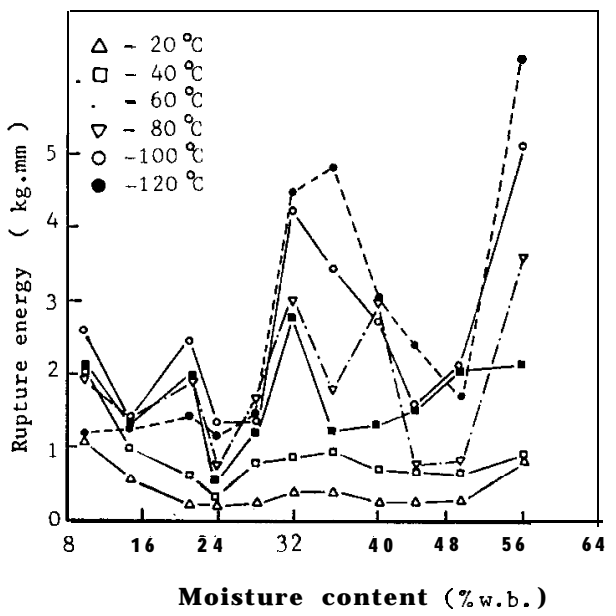

Fig. 5. Effect of moisture content and freezing temperature on the rupture energy of soybeans.

From the pattern of the rupture, stiffness and rupture energy-moisture curves, the effect of moisture contents could arbitrary be divided into 4 zones. These zones are, from $9.8 \%$ to $23.6 \%, 23.6 \%$ to $31.3 \%, 31.3 \%$ to $44.7 \%$ and $44.7 \%$ to $56.2 \%$.

The validity of the assumed moisture zones was tested by dividing the moisture content into intervals of $2 \%$ moisture contents. The area of the intervals under any given temperature was then measured using a planimeter. This area divided by the sum of moisture content at the given interval was taken as the moisture factor, $\psi$. This factor was then plotted versus the 
temperature. This factor was found to be linearly related to the temperature except between $9.8 \%$ and $20.9 \%$ moisture contents. This linear relation was found to have high correlation coefficients (0.951-0. 995). This moisture factor was then related to the temperature in the form,

$$
\psi=\mathrm{a}+\mathrm{bT}
$$

where,

$$
\begin{aligned}
\psi & =\text { Moisture factor } \\
\mathrm{T} & =\text { Temperature (“K) } \\
\mathrm{a} \& \mathrm{~b} & =\text { Constants }
\end{aligned}
$$

The constants a and $\mathbf{b}$ were found to be dependent on the moisture content of the specimen. Eventhen, the relationship was observed to be partitioned into different zones, where the constants were found to be linearly related to the moisture content at each given zone. The constant bwas observed to decrease linearly with increase in moisture content between 22.0 $\%$ and $31.0 \%$. Between $31.0 \%$ and $49.0 \%$ moisture contents, the constant b was increased as the moisture content was increased. The constant, b again decreased as the moisture content was increased from $49.0 \%$ to $56.2 \%$. The effect of moisture content on the cryogenic properties of the soybeans was therefore, partitioned into these zones plus that between $9.8 \%$ and $22.0 \%$. Equations for the moisture factor as affected by the freezing temperature and moisture content were derived and are shown in Table 2.

Table 2. Regression equation for moisture zones partitioned according to moisture factor, $\psi . M=$ Moisture content ( $\%$ w.b.) $\quad \mathrm{T}=$ Temperature ("K) $\mathrm{R}^{2}=$ Regression coefficient

\begin{tabular}{ccc}
\hline Moisture zone & \multicolumn{1}{c}{ Regression equation } & $\mathrm{R}^{2}$ \\
\hline $22 \%$ to $31 \%$ & $\psi=\mathrm{O} .206 \mathrm{M}-0.0008 \mathrm{M} \times \mathrm{T}+\mathrm{O} .014 \mathrm{~T}-3.762$ & 0.973 \\
$31 \%$ to $49 \%$ & $\psi=-0.119 \mathrm{M}+\mathrm{O} .0005 \mathrm{M} \times \mathrm{T}-0.0237 \mathrm{~T}+6.245$ & 0.976 \\
$49 \%$ to $56 \%$ & $\psi=\mathrm{O} .152 \mathrm{M}-0.0006 \mathrm{M} \times \mathrm{T}+\mathrm{O} .0274 \mathrm{~T}-6.939$ & 0.997 \\
\hline
\end{tabular}

When the stress, stiffness and rupture energy were plotted against the inverse of the freezing temperature, linear relations between these parameters and the inverse of the freezing temperature were obtained. Therefore, the parameters were related to the temperature in the form,

$$
\mathrm{Y}=\mathrm{c}+\mathrm{nT} \mathrm{T}^{-1}
$$

where,

$$
\begin{aligned}
\mathrm{Y} & =\text { Any given parameter } \\
\mathrm{T} & =\text { Freezing temperaature ("K) } \\
\mathrm{c} \& \mathrm{n} & =\text { Constants }
\end{aligned}
$$

The constants c and $n$ were found to be linearly related to the moisture con- 
tent with high correlation coefficients (0.899-o. 995). The linearlity of these constants with moisture content was found to be partitioned into two regions, between $9.8 \%$ and $31.3 \%$ and between $31.3 \%$ and $49.4 \%$ moisture contents. The constants at $56.2 \%$ moisture content was found not to fit into the linear relation. From this linear relationship, formulae relating the mechanical parameters and the freezing temperature and moisture content were derived as shown in Table 3. It was therefore, found out that, the effect of moisture content could mainly be partitioned into the two major zones. The failure of the constants at $56.2 \%$ to fit into the linear relation is yet to be clarified further.

Table 3. Equations showing the relationship between mechanical parameters and moisture content and freezing temperature for soybeans. $\mathrm{M}=$ Moisture content (\%w.b.) $\mathrm{T}=$ Temperature ('K) $\mathrm{S}=$ Stiffness (kgf/ $\mathrm{mm}$ ) $\mathrm{Fr}=$ Rupture force (kgf) $\mathrm{E}=$ Rupture energy (kgf. $\mathrm{mm}$ )

\begin{tabular}{lcc}
\hline Parameter & $\begin{array}{c}\text { Moisture } \\
\text { content }\end{array}$ & \multicolumn{1}{c}{ Equation } \\
\hline Stiffness & $9.8-31.3 \%$ & $\mathrm{~S}=-1.701 \mathrm{M}+330.53 \mathrm{M} \times \mathrm{T}^{-1}+446.78 \mathrm{~T}^{-1}+15.28$ \\
& $31.3-49.4 \%$ & $\mathrm{~S}=1.272 \mathrm{M}-539.38 \mathrm{M} \times \mathrm{T}^{-1}+32691.79 \mathrm{~T}^{-1}-84.46$ \\
\hline $\begin{array}{l}\text { Rupture } \\
\text { force }\end{array}$ & $9.8-31.3$ & $\mathrm{Fr}=-1.05 \mathrm{M}+226.88 \mathrm{M} \times ~^{-1}-1695.48 \mathrm{~T}^{-1}+14.41$ \\
\hline $\begin{array}{l}\text { Rupture } \\
\text { Energy }\end{array}$ & $9.8-31.3-49.4$ & $\mathrm{Fr}=0.82 \mathrm{M}-227.43 \mathrm{M} \times \mathrm{T}^{-1}+12943.24 \mathrm{~T}^{-1}-46.14$ \\
\hline
\end{tabular}

The materials at the low moisture zone could be assumed not to have been frozen due to insufficient freezable water (Duckworth, 1971).

The zones above $23.6 \%$ moisture content had sufficient water to make the materials freeze. However, the effect of freezing depends on the amount of water in the materials, as has been stated by Jordan et al (1982). As moisture content increases the amount of ice crystals also increases. At the $23.6 \%$ to $31.3 \%$ zone the stress, stiffness and rupture energy were mainly affected by the amount of ice crystals and strength of the crystals. The amount of these crystals in this zone was not so large to create excessive strains on the samples which would otherwise weaken the samples. The created strains resulting from the ice crystal, reconditioned the samples to take more strains during compression, Srivastavas et al (1974). The reconditioning process was then terminated at $31.3 \%$ moisture content.

At the $31.3 \%$ to $49.4 \%$ moisture zone, the mechanical properties of the materials were mainly influenced by the size, shape and distribution of the ice crystals. The size of the crystals will mainly determine the elastic properties of the specimens. It could be presumed that, the ice crystals in this zone was larger in size than those formed in the preceding zone. The larger size of these crystals will then strain the frozen materials to an extent that they can accommodate only small external strain levels. Katou (1964) reported that when water freezes, the volume occupied by the water is increased by about $9 \%$. Increase in the volume of the frozen material will therefore, increase with increase in moisture content, and therefore, increase in the strain 
with increase in the moisture content. The larger the increase in the strain the weaker the materials become, hence decrease in the stiffness of the materials with increase in the moisture content. Moreover, the ice crystals will force the cells apart, compress the cells and may rupture the cell walls as proposed by Sterling (1968).

In terms of unfrozen water, as the moisture content in this zone (31.3 $\%$ to $49.4 \%$ ) was increased, the amount of the unfrozen water also increases. The higher amount of unfrozen water would decrease the stiffness of the frozen specimens. This assumption could hold true because unfrozen water has been reported to exist in proportion of the free water content rather than to the solid material of the system, (Desrosier, 1970).

The increase in the stress, stiffness and rupture energy at the high moisture zone $(49.4 \%$ to $56.2 \%)$ is not easily explainable from the above given explanations. As there was only one data point above $49.4 \%$ moisture content, more investigations need to be conducted before any concrete conclusions are drawn.

\section{CONCLUSION}

The mechanical properties of soybeans at cryogenic temperatures were observed to be adversely affected by moisture content of the materials. The effect of the moisture content was found to be some how complex than expected. The stiffness, stress and rupture energy were found to be lowest at 23.6 $\%$ below $-40^{\circ} \mathrm{C}$. Stress, stiffness and rupture energy were also found to be decreased at $44.7 \%$ or $49.4 \%$ moisture contents depending on the freezing temperature. The highest values in the stress, stiffness and rupture energy were observed at either $31.3 \%$ or $56.2 \%$ moisture contents depending on the freezing temperature. Above $23.6 \%$ moisture content, stress, stiffness and rupture energy were increased as the freezing temperature was decreased. But depending on the moisture content, the highest values in stress, stiffness, and rupture energy were either obtained at $-100^{\circ} \mathrm{C}$ or $-120^{\circ} \mathrm{C}$. Below $23.6 \%$ moisture content, stress, stiffness and rupture energy were increased when the temperature was decreased to $-80^{\circ} \mathrm{C}$, where maximum values were obtained.

Due to the low rupture energy obtained at $23.6 \%$ soybeans should be cryogenically milled at this moisture content, although the best milling temperature should carefully be selected.

The results reported in this study might not be applicable to other biological materials, due to the difference in the physical and chemical composition of biological materials. The complexity of the effect of moisture content on the cryogenic properties of soybeans shows the need in conducting more experiments on the cryogenic properties of other biological materials, paying attention on the effect of moisture content.

\section{REFERENCES}

Brown, M. S. 1967 Texture of frozen vegetables: Effect of freezing rate on green beans. 
J. Sc. Fd. Agric., 18: 77-81

Brown, M. S. 1977 Texture of frozen fruits and vegetables. J. Texture Studies, 7: 391404

Duckworth, R. B. 1971 Differential thermal analysis of frozen food systems. I. The determination of unfreezable water. J. Fd. Technol., 6: 317-327

Fennema, 0. R. 1975 Freeze preservation. In principles of food science Part 2. Physical principles of food preservation. Marcel Dekker INC., New York, Ch. 6. p. p. 173

Hoeft R. R. P. Bates and E. M. Ahmed 1973 Cryogenic freezing of tomato slices. J. Fd. Science, 38: 362

Hori, T. 1982 Effects of freezing and thawing green curds before processing on the rheological properties of cream cheese. J. Fd. Science, 47: 1811-1817

Jordan, J. L. L. S. Jordan and C. M. Jordan 1982 Effects of freezing to $-196^{\circ} \mathrm{C}$ and thawing on Setaria letescens seeds. Cryobiology, 19: 435-442

Katou, S. 1964 Principles and application of food cold strorage. Korin Shoin Publishers, Tokyo, 323 (in Japanese)

Love, R. M. 1966 Protein denaturation in frozen fish. XI. X. The proportion of tissue water converted to ice. J. Sci. Fd. Agric., 17: 465-471

Love, R. M. and S. B. Haraldsson 1961 The expressible fluid of fish fillets XI. Ice crystal formation and cell damage in cod muscle frozen before regor mortis. J. Sci Fd.

Agric., 12: 442-449

Srivastava, A. K., F. L. Herum and L. A. Balastreire 1974 Effect ot freezing treatment on rupture strength of corn kernels. Transaction of ASAE, 17: 1182-1184

Streling, C. 1968 Effect of low temperature on structure and firmness of apple tissue. J. Fd. Science, 33: 577-580

Wooolf, M. F. 1968 Principles of biometry. D. Van Nostrand Co. INC., London, 70-77, $163-175$ 